\title{
ON THE CONCEPTION OF THE CREATIVE IN NATURAL SCIENCE AND PHILOSOPHICAL REFLECTIONS THEREOF
}

\author{
Nerijus STASIULIS \\ Vilnius Gediminas Technical University, \\ Faculty of Creative Industries, \\ Department of Philosophy and Communication, \\ Traku g. 1, LT-01132 Vilnius, Lithuania \\ E-mails: nerijus.stasiulis@vgtu.It; nerijaus.stasiulio@gmail.com
}

Received 23 June 2015; accepted 26 October 2015

\begin{abstract}
The article discusses creativity as an ontological principle as it is presented in scientific-philosophical attitudes of a Nobel Prize winner for chemistry Ilya Prigogine and Werner Heisenberg's pupil and a former director of the Max Planck Institute for Physics Hans-Peter Dürr. These attitudes are assessed in the light of Heideggerian notions of Being, subiectum, ousia and time and thus they themselves shed light on the potentiality of Heideggerian mode of thinking on the conception of the creative in the postmodern society and science. Bergsonian notion of creativity is also invoked. It is presented as a philosophical basis of the postmodern techno-scientific creativity and is discussed in terms of Heideggerian ecstatic temporality. The juxtaposition of the notions presented by Henri Bergson and Martin Heidegger provides the clue to compare and assess the science-based attitudes of Prigogine and Dürr.
\end{abstract}

Keywords: creativity, Ilya Prigogine, Hans-Peter Dürr, Henri Bergson, Martin Heidegger, ontology.

\section{Introduction}

Creativity has often been related to will as well as opposed to mechanistic approaches to either the subjective sphere (of politics, society etc.) or the objective one (i.e. natural realms of physics, biology etc.). The objective mechanistic principle of cause and effect has its counterpart in the human subject's means-to-ends rationality, both of them being manifestations of the principle of ground. Following the Humean rejection of ontological grounds for the principle of cause and effect, the latter has also become radically subjective. This deprivation of "objective" grounds for the causality principle and the subjectivisation thereof did not, of course, lead to its rejection but, instead, opened the way to new and promising constructivist strategies both in the experimental-technological revealing of the natural realm and the scientific handling of human subjects in the polity or the society or even worldwide. The ever-sharpening 
emphasis on the value of subjective individuality in the religious, the social and the political sphere has progressed concurrently with the techno-scientific attitude and prowess of modernity (stretching into postmodernity). In fact, the two are just different names or manifestations of the same principle that Heidegger (in his Nietzsche lectures) calls subjectity (Subjektität). It is characterized by the identity of object (Gegenstand) and subject: the Gegenstand is such a revealing of Being which is performed by Man turned into the subiectum, i.e. the ground and source of the truth of beings which is in turn the truth as certainty. The latter is techno-scientifically-achieved certainty of the truth of revealed beings in general as well as certainty of one's own innermost individual or collective meaningful (truthful) existence. The meaning-giving, or truth-giving, praxis of individual or collective happiness takes place and part in the technological revelation of beings as a whole on both the cosmological and the politico-social level. The name for this revelation of beings as a whole is creativity: it manifests itself all-in-one in the creative technology-powered endeavour of man and in the conception of the universe (or even Being) itself as creative. The creative will is at the source of both human action and the world at large. The way the will works is techno-scientific ${ }^{1}$.

Described above is the context or situation in which the following juxtaposition of two current non-deterministic physical theories is presented. One of them is that of the chaotic temporal universe by Prigogine, inspired by Bergson's philosophy of élan vital, the other is the Wirklichkeit approach by the pupil and follower of Heisenberg, Dürr, drawing on the German tradition of the thinking of Geist as well as, or including, especially the Heideggerian critique of the Cartesian res. I will assess these two scientific theories in terms of revelation of Being (cf. Stasiulis 2014: 51-70) and I will prefer Dürr's Gestalt approach over Prigogine's chaotic evolution based on my comparison of philosophies of Heidegger and Bergson.

\section{General context in brief}

The mechanistic approach to nature was also materialistic as it described mechanical relations as taking place in a material res or between several material res. The res was usually understood as a sort of particle (an atom, a corpuscle and the like), and this more substantive image of corpuscular res was later to be complemented with that more processual one of a wave. The 19th century also witnessed a growing importance of statistical descriptions whereas the first part of the 20th century was finally forced to drop "matter" (in the sense of "material reality") approaches to the object of physical investigation (cf. Heisenberg 1989: 3-14, 98, 124) and also saw the rise of relativistic physics based on arbitrary (i.e. Lorentz) transformations as well as quantum mechanics based on probability calculus. Although the Einsteinian geometrical attitude as well as the Erwin Schrödinger's equation is still deterministically-oriented, the very modern understanding of causality, which underlies it,

\footnotetext{
${ }^{1}$ For a possible illustration see Černevičiūtè, Strazdas (2014).
} 
has since lost its unshakeable status. Philosophical reflections on the situations have been proposed. However, the philosophical stances, shedding light on the current situation in the sciences, did not fundamentally arise as a response to the present context but rather preceded it.

Modern causality is nothing but the object as Gegenstand, i.e. setting of constant (ständig) presences in physis in accordance with a priori networks such as "laws" of conservation (of energy), of least action and the like (cf. Wittgenstein 2010: §6.3). Gottfried Wilhelm Leibniz, with his monadology, vis primitiva activa and vis viva, already understood this non-material and transcendental nature of (modernly conceived) reality, and he clearly based modern ontology on the a priori ${ }^{2}$ principle of identity. Equiprimordially, the object is revealed in its identity by the self-identical subject. In the Kantian and post-Kantian philosophy there is manifested the transformation of the principle of sheer identity, while identity is crucially understood to be identical with non-identity, the self with the non-self, the object with the subject, the representation with the will, the for-itself with the in-itself, the phenomenon with the noumenon. Accordingly, philosophy revealed the depth of possible contradictions and irregularities underlying the contradiction-free, law-like and regularity-oriented mathematical and thus deterministic, (conception of) reality. Hence, the dire need for statistical descriptions, arbitrary transformations of variables (Lorentz transformations in Maxwell's equations) and probabilistic approach to materialistic-image-free physis had all already for some time been anticipated in philosophy.

The no-more-(sheerly)-deterministic course of the postmodern was also already delineated in Bergson's techno-vitalistic intuitions (Stasiulis 2014: 111-135) which, too, in turn had been enabled primarily by Kantian transcendentalism. Another important reflection on the issue of techno-scientificaly creative postmodernism, beside the Bergsonian élan vital intuition, is the post-Kantian-and-Schellingian thought of Heidegger. It is in terms of these two different strategies of post-Kantian noumenalist thought that we shall outline and assess different stances in the face of the postmodern situation in natural sciences. We take both Bergson's and Heidegger's thought to be post-Schellingian and to be differentiated by the different relation of identity and non-identity, rationality and irrationality, the light and the dark principles which manifest in them (Stasiulis 2014: 265-270). What results are different conceptions of time, approximately corresponding to the differences of the fundamentals which underlie the stances of philosophizing scientists Prigogine and Dürr.

\section{Preliminary comparison: Heidegger and Bergson}

The following are the major differences between philosophies of Bergson and Heidegger. Bergson, in his conception of intuition and élan vital, merges the two principles of identity and non-identity, which accordingly correspond to the mechanistic conception

\footnotetext{
${ }^{2}$ We are justified in describing Leibniz's contribution in transcendental aprioristic terms, even though he was a pre-Kantian because Leibnizian notions can be considered precursory of Kantian ones (De Risi 2007: 300).
} 
of the universe and the indeterminacy of the will. The mechanistic understanding here is retained but it is united with and subordinated to the driving life force, gnawing into the future. It is but a Galilean physics driven to its ontological conclusion: the principle of sheer activity of the subiectum (or paradoxical activism-passivism (cf. Stasiulis 2011, 2014: 63-65, 140-147) has underlain this physics since its very inception. The Galilean physics and its philosophical ratio - the subjectum - is, according to Heidegger, Being-historically dependent on the ancient Greek principle of presence/essence, or ousia and energeia, and, to wit, on the Being-forgetful manifestation thereof $^{3}$. Therefore, Heidegger is able to evaluate this revelation of Being in terms of his authentic repetition (or retrieval) (Wiederholung) of the Greek revelation of ousia. Ousia is now construed not as sheer constant presence but as a unity of the three ecstasies of time, gathered by the fourth dimension thereof, i.e. Being (Beyng). Whereas the authentic construal indicates the primordial unity of the three separate ecstasies, the inauthentic one turns out to consist in a radical separation of the three ecstasies and their falling into three separate, though historically as well as ontologically, equiprimordially interconnected inauthentic ontologies.

The first one is the inauthentic shape of the ecstasy of the past - mechanistic determinism. The second one is the inauthentic shape of the present - atomism or corpuscularianism. Both of these are deprived of their ontological priority by Bergson. But the third one is the inauthentic shape of the future - voluntarism, which understands being as a creativity, radically surmounting limits, or pure time, the in-andfor-itself living futureness (also see Stasiulis 2014: 120-125). This happens to be the Bergsonian élan, which is also the philosophical basis of Prigogine's slogan "time precedes existence" (Prigogine 2006: 27, 96, 139, 201). Just like Bergson, Prigogine places pure futureness, or time, at the source of reality and, for him, the equations and viewpoints of Galilean or post-Galilean physics are temporary manifestations of this source. Time, in Prigogine's scientitic view of nature, is inextricable. We can also notice here a principal accordance with the Kuhnian notion of paradigm shift which is but a way progress (from Latin pro-gredere) moves on. Is it possible that the very notion of progressing time and paradigm shift is not a dispensing from the older ("classical") physics but is its very coming to its very essence, i.e. the full manifestation of the creative subject?

\section{Discussion of natural scientific approaches: Prigogine and Dürr}

\section{A. Prigogine's approach}

Prigogine maintains Newtonian laws to be insufficient and calls for a new paradigm of science, which, unlike its predecessor, will account for an importance of time and thus include chaos among its basic principles. This is supposed to yield new laws of nature which will also be able to deal with what Prigogine calls the Epicurean problem

\footnotetext{
${ }^{3}$ An indication of this is that Gallilean physics, which inspires Bergson's processual (deterministic) living intuition (cf. Arendt 1998: 305; Stasiulis 2013: 77), is nominalist (cf. Šaulauskas 2013: 15).
} 
of freedom. To remind, Epicurus was dissatisfied with the conception of a determined straight-forward motion of atomic particles and introduced into this motion a clinamen, an arbitrary going off the straight path of a particle, which was to account for or make possible (human) freedom. The problem of freedom is definitely, and especially in Bergson's thinking, equated with the problem of time (i.e. of novelty, creativity, inventiveness) and vice versa. Thus, Prigogine sees an obvious analogy between the Galilean-Newtonian deterministic view of the universe and the view Epicurus opposed, on the one hand, and between the Epicurean solution and his own Bergson-inspired time-based chaotic universe, on the other hand. We must emphasize the familiar importance of the influence of Bergson's thinking on the view of Prigogine because it is only because of this radically new philosophical approach developed by the French philosopher that the Belgian scientist is able to make his transition "from probability to irreversibility", that is from the probabilistic treatment of the still-deterministic equations in the context of quantum mechanics to the fundamental insertion of the arrow of time into the very fabric of isness and, what is more, to the ontological priority of the surge of time. While in the classical deterministic physics (projected according to the Cartesian method onto the Cartesian system of axes) there had been no place for indeterminacy and novelty as it had asserted the ontological priority of the abstract geometrical space over the merely-illusory time, Prigogine's new paradigm claims to bring the end of deterministic certainty as well as to reflect the actual complexity of the world. He also considers human ("subjective") creativity to be part of a more fundamental tendency of time, manifesting itself universally on every level of nature. To note, Prigogine supports his philosophy with his own Nobel Prize winning scientific research on self-organising systems and dissipative structures.

Here are two major characteristics of the Belgian's stance. Firstly, Prigogine's approach is in tune with (post)modernity's progressive mood, its evolutionary inclination. Furthermore, it should not be considered to radically revolutionize the modern mode of thought but exactly to bring it to its vitalistic fruition or essence. Darwinian mechanistic evolution was compatible with the materialistic natural science of his time, whereas modern natural science of that time (19th century) still had not caught up with its virtual essence. It took at the very least half a century more for it to both acquire a free relation to its materialistic imagery and to achieve a technological mastery over both nature and society (as, for instance, is exemplified in Theodor W. Adorno, Jean Baudrillard etc.). It is only then that it can construe its own self as but a manifestation of virtual vitalistic evolutionary creativity, a tool at the hands of a surge of time (or, in our terms, as the principle of subiectum conceived as the principle of physis (nature) itself).

Secondly, Prigogine's view is clearly reliant on the duality of past and future, determinacy and indeterminacy, or, to trace it to its most remote historical roots, on the Epicurean mode of thinking. Because it was the atomism of the latter that introduced the very problem of determinism versus freedom. It was only by a twist of Democritus' thought that Epicurus was able to do it because the problem of determinism versus freedom had no place in Democritus' thought. The atom for Democritus 
was but a manifestion of the principle of peras, or limit, according to which all ancient Greek thought was unfolding. This peras, or essence, was conceived to be in unity with non-essence, hence the images of both atoms and void. This unity was what the movement of the singularily manifested universe consisted in. The ancient Greek problem was that of the unity of ousia ("essence") and kinesis (movement, movedness) which is totally alien to the posterior problem of determinism and indeterminism (cf. Heidegger 1979; Stasiulis 2014: 139, 167). What is more, it is only on this inauthentic disjunction of essence and non-essence that the philosophical basis of (post)modern science can thrive. Thus, Being is divided into regions of mechanicality and spontaneity and various relations thereof. Prigogine's view is also based on this division (Stasiulis 2014: 167-168).

\section{B. Dürr's approach}

The notion of alte Physik, which is contradicted by Dürr (2012), is the following. The world, or the existence, is ultimately composed of material particles which move and interact mechanistically according to laws uncovered by the natural scientist. What is more, the idea of the elementary particle is that it has no "form" but only "matter". The forms of the visible world we live in arise from combinations of particles that come about according to the so-called laws of nature, given enough - indeed, a "very long" span of - time. Also, the material particles are individual, separated from one another, as it were, lonely, and estranged in (geometrical) space. Thus, they interact over long distances "due to gravity" and, given sufficient time, form molecules and so on and so forth. To sum up, the idea is that of "material" separate elementary building blocks of the universe, which interact in accordance with (natural) laws projected in geometrical space and thus give rise to the visible world and its "subjective" qualities.

As Heidegger already noticed, this idea of "matter" as elementary substance was already available in ancient Greece and was discredited by Aristotle's superior notion of ousia as form, or eidos (morphē) (Heidegger 1979: 268-282, 294-301). Underlying Aristotle's theorizing was also a pre-conceptual understanding of immaterial - "transcendental" - interrelatedness of things, explained and thematized by Heidegger in his analysis of the Zusammenhang of Zeug (Heidegger 2006: 63-114; Stasiulis 2014: 169 and below). Post-Cartesian physics sought to uncover stable laws operating in reality, i.d. it narrowed the question of Being and the world to the most proximally available beings, the res (Stasiulis 2011: 19-20). But, as it was in modern times already noted by Friedrich Wilhelm Joseph Schelling, the stability of reality is but a surface under which there lies the original irregularity of the ground (cf. Heidegger 1995: 165-167; Schelling 2006). While the activity, underlying the visible, actual things, was by Aristotle called dunamis, or (in the usual Latin translation) potentiality. The idea of material elementary particles had been unpopular among great German thinkers at least since Leibniz (through Immanuel Kant, Georg Wilhem Friedrich Hegel, Arthur Schopenhauer, Heinrich Hertz etc.) but it was probably only in the 20th century thinking of Heisenberg that the very development of physics itself gave the opportunity to give up the old "materialistic" notion. Now, for Heisenberg and his school, at bottom 
there is no matter but potentiality. Aristotle's wisdom is retrieved and proves fruitful in the context of the (reflection on) the results of contemporary natural science.

This is exactly what Dürr asserts. He introduces the notion of haps $(\leftarrow$ happen, in German: Wirks $(\leftarrow$ wirken) which is to replace the notion of particles. It means that at bottom there is no matter, no material particles but only potentialities. Potentialities are active and they come into existence every instant. In this sense, the world that we see is being created (and upheld) every instant. Thus, at bottom there is not reality (Lat. realitas $\leftarrow$ res), but Wirklichkeit, or actionality. The structure of Wirklichkeit is not that of individual material res, but that of primordial relation.

Professor Dürr presents the prehistory of this idea. The old solar-system model of atom proposed by Niels Bohr was calculated not to work as electric forces were unable to keep the electrons going around the nucleus and thus they were supposed to "fall". The conclusion was drawn that there are no electrons, no matter, but only the relation (described by the mathematical equation). According to Loius de Broglie, the electron is but a swinging wave, a nothing that swings - not a wave at all, to be precise, but a complicated form of swinging. All material images of the atom are just superficial illustrations; in fact, there is no matter, but only a Gestalt, a primordial relation. Therefore Heisenberg wanted to get rid of the atom itself and turned to the Aristotelian notion of potentiality and he also appreciated the Platonic immaterial principles exposed in Timaeus and the fire of Heraclitus (Heisenberg 1989: 12, 29-30, 39). It was also his intention to do away with Cartesian dualism and to demonstrate the closeness or even identity of his thinking and of his Catholic faith, thus doing away with the absurd debate of science versus religion. Both science and religion have to do with the revelation of the one, or Wirklichkeit.

Thus, according to the afore-said interpretations of quantum physics, there is at bottom the one, the unity. Both Dürr's approach and that of Prigogine's claim to be holistic. However, they must not be identified even in the most general outline. How are the two understandings of unity different?

\section{Concluding comparison: Dürr and Prigogine}

Both Heidegger and Bergson assert the primacy of the continuum, the one. But for Heidegger this one is ecstatically giving rise to the three dimensions of time without coinciding with it and thus it is the fourth dimension - Being - which borders on the ineffable; while for Bergson the élan coincides with time and with the surge of life, or creativity. Bergson's one is a philosophical stance that can be grasped via subject's (self-)intuition, in other words, by the urge of creativity, while Heidegger's one is the pre-philosophical source of thought, not reducible to sheer activity and to the subjectum (cf. Stasiulis 2014: 186-199). Hence, Prigogine's Bergson-inspired claim to the new chaotic laws of nature that have grown out of the older physics and chemistry is in line with the Kuhnian notion of progress by radical paradigm change, whereas Dürr's new holistic physics, he emphasizes, is not yet another one of paradigms; because paradigms are ways of intervening into the prior whole of physis, ways we grasp the world, but we always experience more than we can grasp, the whole is always more 
(Dürr 2014). This relation to physis, to emphasize, transcends any one of all possible paradigms. While Prigogine also speaks about a holistic approach, his proposed holon is perfectly identical with the chaotically described within-worldly entities; according to him, it is part and parcel of possible (future) natural sciences.

But, in line with the Heideggerian ontological difference, Dürr's holon, just like Eckhartian Wirklichkeit, is not entity-like and is ineffable. Still, this holon harbours within itself the original relation of all potential and actualising things and this interrelatedness is understood as forms, or Gestalts, according to which worldly entities come into being. Because of the Gestalts, the indeterministic Wirklichkeit is also not arbitrary; the future is open, unpredictable and still within ontological bounds. Whereas Prigogine's universe is purely future-orientated and radically open. Also, Prigogine's chaos seems to be radically solitary and for-itself in accordance with the oneness and self-sufficiency of Bergson's élan vital and its abolition of the nothing (Stasiulis 2013: 77-80). But Dürr, like Heidegger, takes the nothing into account and his chaos is a coupled chaos. According to him, it is precisely this coupled chaos (for instance, running is like falling on one foot, then on another, and so forth) which Gestaltwise - gives rise to order and to life.

The life-giving Gestalt is beyond intellectualistic analysis and intellectual grasping and is more like having an inkling (Ahnung haben). Contrary to Prigogine, who is emerged in the particular techno-scientific findings of his day, Dürr thinks beyond old paradigm-shift physics and also beyond current biology which he considers to be but alte Physik (Dürr 2014). While vitalism still maintains that organisms are fundamentally made of cells, matter etc., physicists like Dürr have come to the conclusion that there is no matter and that there is a deeper principle, the Geist, which is the driving force. Life and world are not clock-work, even if terribly complicated and yea chaotically described. The "clock gone mad" would still be the subiectum. Thus, it would be absolutely active, whereas the Geist- and Gestalt-based thought is not subjected to utter activity and is rooted in an original passivity. The subiectum turns out to be a queer vitalistic identity of identity and non-identity, the irrational and the rational, whereas the passivity-rooted original ${ }^{4}$ activity and life is the Heideggerian ecstasy of the two aspects, i.e. it is beyond and has aufgehoben the opposition of deterministic space and vitalistic time, of rationality and irrationality.

Heideggerian retrieval of Aristotelian and ancient Greek thought in the context of the 20th century's techno-scientific, subjectist (meta)physics retrieves the wisdom of the unity of time and space, rationality and irrationality, action and passion, thinking and sensuality, which are also equiprimordially the unity of the three-ecstasies of time, the authentic ousia. Dürr's philosophical physics can be considered a fair illustration of Heideggerian achievement and of its fundamental relevancy to the sphere of natural sciences.

\footnotetext{
4 “Originality" originally means rootedness and even primordiality rather than sheer novelty.
} 


\section{Conclusions}

Modern science sprang as an early manifestation of the principle of the subiectum which in turn is a phase in the development of the Western ontology of ousia, or a shape thereof. This early Galilean-Newtonian manifestation consisted in a materialistic, mechanistic and deterministic conception of beings and reality. As the subiectum historically entered its more mature phase, it revealed itself as a creative life force manifesting itself by means of technological prowess. Scientific ontology has been ridding itself of its materialistic imagery and its deterministic bias and has been discovering creativity's ontological fundamentality. However, the fundamental notion of creativity is equivocal as illustrated by the actionality approach of Dürr and the chaotic temporal universe approach of Prigogine. This equivocality calls for a more philosophical orientation and an ontological assessment of physical or physics-based approaches. Heideggerian thinking of ousia as a Being-rooted unity of the three ecstasies of time proves to be a seminal way of both approaching and assessing contemporary developments in and situation of natural science in its postmodern context because it provides an insight into both historical and ontological bases of current scientific stances as well as a potential to sublate (aufheben) their philosophical foundation. Unlike Bergsonian strategies of thought, it is not overwhelmed with the subjectist techno-vitalistic attitude but rather absorbs it into a form of another thinking. While this another thinking of Being is (yet) entirely formal and contains endless possibilities to specify its content, this articles has indicated two rather specific directions of investigation. The first one is an interpretation of the results of natural sciences based on the German and Aristotelian tradition of thought, invoking the notions of Geist, Gestalt, or form, and potentiality. This line was taken up by the school of Heisenberg. The second one is a reconstrual of Democritus' ancient atomism in the light of the new reflection on ousia and the non-materialistic approach to particles in contemporary physics. This line is to be taken up in future research and it is also relevant in terms of the basis of the concept of the creative because it has to do with the very ontological centre of this concept as it lies at the root of 1) the possibility of the causal unveiling of the world, 2) of the notion of a self-sufficient individual whose happiness is presented as a goal of the creative society, and 3) of the issue of freedom which is to be rooted in Beyng.

\section{References}

Arendt, H. 1998. The Human Condition. Chicago: The University of Chicago Press. http://dx.doi.org/10.7208/chicago/9780226924571.001.0001

Černevičiūtè, J.; Strazdas, R. 2014. Kūrybingumo sampratų raida: nuo genijaus ị kūrybines sistemas, Santalka: filosofija, komunikacija 22(2): 113-125. http://dx.doi.org/10.3846/cpc.2014.10

De Risi, V. 2007. Geometry and Monadology: Leibniz's Analysis Situs and Philosophy of Space. Knobloch, E.; Scholz, E. (Eds.). Basel, Boston, Berlin: Birkhäuser.

http://dx.doi.org/10.1007/978-3-7643-7986-5 
Dürr, H.-P. 2012. Ganzheitliche Physik [online], [cited 22 December 2014]. Available from Internet: https://www.youtube.com/watch?v=rAakoWFZpDA

Dürr, H.-P. 2014. Ist Biologie nur Physik... von Gestern? (Vortrag) [online], [cited 22 December 2014]. Available from Internet: https://www.youtube.com/watch?v=nArFh59EnkM

Heidegger, M. 2006. Sein und Zeit. Max Niemeyer Verlag: Tübingen.

Heidegger, M. 1995. Schellings Abhandlung über das Wesen der Menschlichen Freiheit (1809). Tübingen: Max Niemeyer Verlag.

Heidegger, M. 1979. Vom Wesen und Begriff der Physis. Aristoteles, Physik B, 1, in Hermann, von F.-W. (Hrsg.). Gesamtausgabe, I. Abteilung: Veröffentlichte Schriften, 1914-1970. Bd. 9: Wegmarken. Frankfurt am Mein: Vittorio Klostermann.

Heisenberg, W. 1989. Physics and Philosophy: The Revolution in Modern Science. London: Penguin Books.

Prigogine, I. 2006. Tikrumo pabaiga: laikas, chaosas ir nauji gamtos dèsniai. Vilnius: Margi raštai.

Schelling, W. F. J. 2006. Philosophical Investigations into the Essence of Human Freedom. Schmidt, D. J. (Ed.). Series: SUNY Series in Contemporary Continental Philosophy. Albany: State University of New York Press.

Stasiulis, N. 2014. Aristotelio filosofijos reikšmé Heideggerio mastyme: Daktaro disertacija. Humanitariniai mokslai, filosofija $(01 \mathrm{H})$. Vilniaus universitetas (neskelbtas šaltinis).

Stasiulis, N. 2013. Heidegeriškoji oúoía interpretacija kaip atsakas į bergsoniškają klasikinio mąstymo kritiką, Problemos 83: 73-85.

Stasiulis, N. 2011. Parankiškumas kaip būties mąstymo anticipacija M. Heideggerio Būtyje ir laike, Problemos 79: 17-32.

Šaulauskas, M. P. 2013. Dvilypė filosofinio moderno savigrinda in pectore - tvarusis hypokeimenon ir atomon sajungos trapumas, Problemos 83: 7-21.

Wittgenstein, L. 2010. Tractatus Logico-Philosophicus, in Project Gutenberg's Tractatus Logico-Philosophicus, by Ludwig Wittgenstein. Ogden, C. K. (General Ed.). Series: International Library of Psychology, Philosophy and Scientific Method. EBook \#5740: 23-90 [online], [cited 1 December 2014]. Available from Internet: http://www.gutenberg.org/files/5740/5740-pdf.pdf

\title{
APIE KŪRYBIŠKUMO KONCEPCIJĄ GAMTOS MOKSLUOSE IR FILOSOFINIUS JOS SVARSTYMUS
}

\author{
Nerijus STASIULIS
}

\section{Santrauka}

Straipsnyje aptariamas kūrybiškumas kaip ontologinis principas. Pateikiamos chemijos srities Nobelio premijos laureato Ilya Prigogine'o ir Wernerio Heisenbergo mokinio bei buvusio Maxo Plancko fizikos instituto direktoriaus Hanso-Peterio Dürro mokslinès ir filosofinès pažiūros, grindžiamos šiuo principu. Jos vertinamos pasitelkiant haidegeriškąsias būties, subiectum, ousia ir laiko aptartis, kurios pačios iliustruoja kūrybiškumo sąvokos postmoderniojoje visuomenèje ir moksle haidegeriškojo apmąstymo būdo potencialą. Taip pat pa- 
sitelkiama bergsoniškoji kūrybiškumo samprata, kuri laikoma postmoderniojo technomokslinio kūrybiškumo filosofiniu pagrindu ir aptariama haidegeriškuoju ekstatiškojo laikiškumo požiūriu. Gretinant Henri Bergsono ir Martino Heideggerio sampratas, lyginamos Prigogine’o ir Dürro gamtamoksliškai grindžiamos pažiūros.

Reikšminiai žodžiai: kūrybiškumas, Ilya Prigogine'as, Hansas-Peteris Dürras, Henri Bergsonas, Martinas Heideggeris, ontologija. 